\title{
Real Exchange Rate and Manufacturing Export Competitiveness in Eastern Africa
}

Fetene Bogale Hunegnaw

Adama Science and Technology University, Adama, Ethiopia

\begin{abstract}
This paper investigates the effects of real exchange rates on manufacturing exports in 10 East African countries. The study uses pooled mean group and mean group estimators with an Autoregressive Distributed Lag procedure to analyze disaggregated manufacturing exports, unlike past studies that often examined aggregate exports by adopting traditional empirical methods subject to various shortcomings. The estimation results suggest that in long-run depreciation of the Real Effective Exchange Rate improves all classification of manufactruing exports. Our results are more or less consistent with the standard theory. The elasticity is relatively low, except for low-skill manufacturing exports. In the short run, real exchange rate depreciation improves exports of labor-intensive, low-skill, and medium-skill technology-intensive manufacturing. In contrast, depreciation of the real effective exchange rate worsens high-skill technologyintensive exports. Another findings suggest that exchange rate devaluation matters for export performance in Eastern Africa. Nevertheless, the magnitude of this elasticity is low and remains below the findings for Sub-Saharan African and other developing countries. Positive and elastic manufacturing exports with respect to domestic real GDP shows the importance of economic growth to the performance of manufacturing exports. Therefore, policies aimed at boosting exports in the long term should aim to provide a conducive environment for economic growth rather than continuous devaluation of a domestic currency.
\end{abstract}

\footnotetext{
* Corresponding Author: Fetene Bogale Hunegnaw; College of Social Science and Humanities, Adama Science and Technology University, Adama, Ethiopia, Tel: 251910242117, Fax: 251-221-100038, P.O.Box: 1888, E-mail: fetene1984@gmail.com
} 
JEL Classification: F3, F4

Keywords: ARDL Model, Eastern Africa, Exchange Rate, Manufacturing Exports

\section{Introduction}

Africa's exports are predominantly unprocessed primary products; in contrast, exports from East Asia mainly comprise manufactured products. This difference in export structure is often said to have contributed to the large difference in these regions' growth rates over the past few decades. The rapid expansion of manufacturing exports from East Asia in the last three decades has been an engine for that region's economic growth. This surge has been accompanied by a shift in the commodity composition of these countries' exports toward machinery categories, which are among the fastest growing sectors in world trade (ADB 2007). Although adjustment speeds have varied, countries in the region initially focused on technologically simple, labor-intensive goods such as apparel and footwear and then moved to a range of more capital- and technologyintensive goods such as technologically sophisticated items, especially electrical and nonelectrical machinery. This process was initially undertaken by Japan, followed by Hong Kong, South Korea, Singapore, Chinese Taipei, and more recently, Indonesia, Malaysia, the Philippines, and Thailand. In contrast, the transformation of export composition from primary commodities to manufacturing commodities in Sub-Saharan Africa (SSA) and East Africa, in particular, is relatively static. In Indonesia, Malaysia, and Thailand, the share of manufacturing exports rose from around $6 \%$ in 1965 to $41 \%, 61 \%$, and $77 \%$, respectively, in 1992. In comparison, in SSA, manufacturing exports were 7\% in 1965 and only 8\% in 1990 (Amakom 2012).

Such a shifting of resources from the primary to the secondary sector has been recognized as a driver of the development process (Nouira, Plane and Sekkat 2011). Most pioneering experts on the development process, from Lewis (1954) to Chenery (1986), have supported this view. Several theoretical arguments underlie the need to stimulate the manufacturing sector as part of the development process, especially through an increase in a country's exports, in the context of the global economy. According to the aforementioned economists, first, as income increases, demand for manufactured goods increases more than that for primary products. Hence, growth prospects for a country's 
exports are higher if it specializes in manufacturing (Hausmann, Pritchett and Rodrik 2005). Second, development of the manufacturing sector induces substantial dynamic productivity gains, and consequently, induces growth arising from economies of scale, learning effects, and externalities among firms and industries (Hausmann, Pritchett and Rodrik 2005). Third, owing to relatively higher price elasticities of both demand and supply, developed countries' economies are less susceptible to price swings (Elbadawi 1999).

The common factors behind the collapse and poor performance of many African economies in the period since African nations gained independence in the 1960s are the low growth of exports in general and manufacturing exports in particular (Amakom 2012). One major factor that has hindered the growth of manufacturing exports has been overvaluation of foreign exchange rates (Collier and Gunning 1999). According to Collier and Gunning (1999), this overvaluation was a common factor in the dramatic decline in export volumes during the 1970s and early 1980s in Ghana, Uganda, and Tanzania. Reversal of this policy was a key change that triggered growth of export volumes. The evidence seems clear that policies that avoid an overvalued Real Exchange Rate (RER) are a precondition for growth of manufacturing exports. All countries that have successfully promoted manufacturing exports have experienced RER depreciation, leading domestic relative price of tradable good to rise relative to prices of non-tradable goods (Sekkat and Varoudakis 2000).

Several studies have investigated the effect of exchange rates on manufacturing exports in both developed and developing countries using different econometric methods. Sekkat and Varoudakis (2000) empirically assessed the impact of exchangerate policies on manufacturing export performance for a panel of major SSA countries over the period 1970 1992 and confirmed that depreciation clearly fosters manufacturing exports' performance. Thorbecke and Zhang (2009) found that an appreciation of Chinese currency would substantially reduce China's exports of clothing, furniture, and footwear. Zia and Mahmood (2013) confirmed that manufacturing sector exports improve following exchange-rate devaluation, but this growth is offset by exchange rate volatility. Empirical evidence by Grobar (1993) showed that some categories of manufacturing exports from less-developed countries are negatively affected by RER uncertainty.

In recent years, East African countries have continously devalued their currencies with the intention to improves trade balances through boosting exports, particularly manufacturing exports. However, their exports, and particularly manufacturing export 
growth, has not been satisfactory. In fact, the efficiency of currency devaluation to promote exports in this region is under debate. Nevertheless, the literature examining the effect of devaluation on manufacturing exports in East African countries is scant. Moreover, some existing studies have focused on cross-country analyses and are static in nature. They have not addressed short- and long-run effects of foreign exchange rates on manufacturing exports and used ordinary least squares, even though several variables in the exports model were non-stationary. Therefore, the null hypothesis will be wrongly rejected in such analyses (Engle and Granger 1987). Others used the Vector Error Correction Method (VECM) for small observations (Toda 1995). Moreover, with few exceptions, all of the prior studies focused on aggregate manufacturing exports.

Using aggregate data causes aggregation bias; significant price elasticity in one manufacturing export sector could be offset by insignificant elasticity in another manufacturing export sector. The sign of Real Exchange Rate (RER) effects may vary among different manufacturing classifications. One classification might be in line with aggregate manufacturing exports, whereas others might be inconsistent with aggregate manufacturing exports. ${ }^{1}$ Therefore, these gaps open a new research area in the study of manufacturing export elasticities. This study attempts to investigate the relationship between disaggregated manufacturing exports and the Real Effective Exchange Rate (REER) by using an autoregressive distributed lag model.

The rest of the paper is constructed as follows. In the next section, we explain our data and model, and Section III discussed the empirical results. Lastly, Section IV concludes the paper, including our suggestions.

\footnotetext{
${ }^{1}$ Ardalani and Bahmani-Oskooee (2007) and Bahmani-Oskooee and Wang (2007) suggested that depreciations have a negative impact on sectoral trade balances in the long run, even though depreciation of the domestic currency generally leads to long-run improvements in the aggregate trade balance.
} 


\section{Data and Model}

\section{A. Data description}

The empirical analysis used for manufacturing exports is based on SITC 3 classification $\left(X_{S}\right)$, REER, domestic real GDP $\left(Y_{D}\right)$, and foreign real GDP or real GDP of the top 10 trade partners $\left(Y_{F}\right)$. The annual frequency of this series was obtained from 1995 to 2013. We construct REER as the weighted average RER of 10 trade partners. The RER was obtained by employing domestic and US price indices. The exchange rate is defined as domestic currency per unit of foreign currency. We construct the REER based on the country's top 10 trade partners' trade weight by following Thapa (2002)'s procedure

$$
R E E R=\sum_{j=1}^{n}\left(R E R_{i j} * \theta_{j}\right) \quad \text { and } \quad R E R_{i j}=N E R_{i j} *\left(\frac{C P I_{i}}{C P I_{j}}\right)
$$

where NER is the nominal exchange rate against trade partner $j ; n$ is the number of trade partners; $\mathrm{CPI}_{i}$ is the country's own consumer price index; $\mathrm{CPI}_{j}$ is the consumer price index of trade partner $j$; and $\theta_{j}$ is the average trade weight of trade partner $j$ for the years 1995 2013:

$$
\theta_{j}=\frac{(\operatorname{Export}(i j)+i m p o r t s(i j))}{\sum_{j=1}^{n}(\operatorname{exports}(i)+\operatorname{imports}(i j))}
$$

where $j=1,2, \ldots, 10$; top trade partners (Boumbouya 2009) and exports and imports are the average for the years 1995 2013.

Ten East African countries are considered: Burundi, Ethiopia, Kenya, Madagascar, Malawi, Mauritius, Seychelles, Tanzania, Rwanda, and Uganda. ${ }^{2}$ Data are obtained from the World Bank, International Monetary Fund, the World Trade Organization, the United Nation Conference on Trade and Development, and the Penn World Table version 8.0.

\footnotetext{
${ }^{2}$ The Eastern Africa region is composed of Ethiopia, Kenya, Tanzania, Zimbabwe, Zambia, Mozambique, Madagascar, Rwanda, Burundi, Malawi, Somalia, Mauritius, Djibouti, Eritrea, Seychelles, South Sudan, and Comoros, based on 2010 UN classifications. Among them, 10 countries for which data were available were considered.
} 


\section{B. Model and techniques}

Based on Dornbusch (1980) and Meese and Rose (1990), the simple relationships among export supply, exchange rates, and income are defined as

$$
\begin{gathered}
X=\left(\operatorname{RER}, Y_{D}, Y_{F}\right) \\
\operatorname{Ln}\left(X_{S}\right)_{i t}=\delta_{1} \ln R E E R_{i t}+\delta_{2} \ln \left(Y_{D}\right)_{i t}+\delta_{3} \ln \left(Y_{F}\right) i_{t}+\varepsilon_{i t}
\end{gathered}
$$

where $X_{\text {sit }}$ is the quantity of s classified manufacturing exports for country $i$ at time $t$; $\operatorname{Ln}(R E E R)_{i t}$ is the natural log of the REER for country i at time $t ; \ln \left(Y_{D}\right)_{i t}$ is the natural $\log$ of the country $i$ 's own real GDP at time $t$; and $\ln \left(Y_{F}\right)_{i t}$, is the natural log trade weight of real GDP ${ }^{3}$ of foreign country $i$ at time $t$.

The ARDL approach is used to estimate the empirical trade balance model. To estimate an ARDL equation for panel data, Pesaran et al. (1999) developed a mean group estimator (MG) and a pooled mean group estimator (PMG). The $\mathrm{MG}^{4}$ estimator imposes no restrictions on the parameters of ARDL specification and derives the longrun parameters obtained from individual ARDL estimates, whereas the PMG estimator constrains the long-run parameters to being the same but allows intercepts, error correction terms, and for the short-run parameters to differ freely across countries. The ARDL approach offers the following advantages. First, unlike other cointegration procedures, ARDL can be applied to a fractionally integrated series. Second, ARDL is suitable even for small samples (Gujarati 2012). ${ }^{5}$ Third, the ARDL technique provides unbiased estimates for the long-run model and valid $t$-statistics even if some regressors are endogenous (Harris and Sollis 2003). This reflects the fact that the model's dynamic specification is sufficiently augmented so that the regressors are strictly exogenous and the resulting residual is serially uncorrelated. Thus, in the case of difference-stationary variables, appropriate augmentation of regressor order is sufficient to simultaneously

\footnotetext{
${ }^{3} Y_{F}=\sum_{\mathrm{j}=\mathrm{i}}^{\mathrm{n}}\left(\Theta_{\mathrm{j}^{*}} \mathrm{Y}_{\mathrm{j}}\right),\left(Y_{F}\right.$ is trade weighted top 10 trade partners real GDP for country $i ; \Theta_{j}$, average trade weight of trade partner country for years $1995 \sim 2013, j=1,2, \ldots ., 10$ is top 10 trade partners. $Y_{j}$, is real GDP for $j$ foreign trade partner country (Chinn 2006).

${ }^{4}$ This is the least restrictive procedure, and it allows for heterogeneity of all the parameters (imposes no cross-country restriction); It consists of estimating separate regressions for each country and computing averages of the country-specific coefficients. The assumptions are quite strong - they require that the group-specific parameters are distributed independent the regressors and that the regressors are strictly exogenous. This estimation model does not take into account the tendency for the same economic conditions to prevails across countries in the long run; for details, see Pesaran et al. (1999).

${ }^{5}$ Past studies have criticized use of Johansen's techniques when few observations are used. For example, Toda (1995) suggested that fewer than 100 observations can lead to misleading results.
} 
correct for residual serial correlation and the endogeneity problem in the estimation of long-run parameters.

The presence of long-run relationships in variables is often determined using Johansen's cointegration technique. However, the power of Johansen's test in a multivariate system with small sample sizes can be severely limited. To solve this problem, the panel cointegration approach and $t$-statistics, proposed by Pedroni (2004), is used.

The specification for the ARDL system of equations is formulated as follows, based on Asteriou and Hall (2007):

$$
\ln X_{S j t}=\alpha_{j t}+\sum_{i=1}^{n} \delta_{0 j t} \ln (X s)_{j t, t-i}+\sum_{i=0}^{m} \delta_{n j t} \ln Z_{j n, t-1}+\mu_{j t}+\varepsilon_{j t}
$$

This model can be re-parameterized as an ARDL-VECM system as follows:

$$
\begin{aligned}
\Delta \ln (X s)_{j t}= & \phi_{j} \ln (X s)_{j, t-1}-\alpha_{j}-\delta_{n j} \ln \left(Z_{j, t-1}\right)+\sum_{i=1}^{n-1} \beta_{j 0} \Delta \ln (X s)_{j, t-i} \\
& +\sum_{i=0}^{m-1} \beta_{n j} \Delta \ln Z_{j, t-i}+\mu_{j}+\varepsilon_{j t}
\end{aligned}
$$

where $i=$ number of lags; $j=1,2,3,4, \ldots, 10$ is number of countries; $Z_{j, t-1}$ is the $(\mathrm{K} \times 1)$ vector of explanatory variables $X=\left(R E R, Y_{D}, Y_{F}\right)$ for country $j ; \mu_{j}$ is the countryspecific effect; $\varepsilon_{i t}$ is the error term; $t$ denotes time; parameters $\beta_{j n}: n=1,2,3$ are the shortrun dynamic coefficients; parameters $\delta_{n}: n=1,2,3$ are the long-run coefficients; and $\theta_{j}$ represents the error correction coefficient.

Both MG and PMG estimations require selecting the appropriate lag for the individual country equations. This selection is made using the Schwarz Bayesian criterion ${ }^{6}$ (SBC). We assume that in the long run, countries in this region are expected to have similar sectoral structures, extent of liberalization, and monetary policies. In the short run, however, their monetary policy, exchange-rate policy, scope of liberalization, and other external and internal shocks are expected to be heterogeneous. Because the time span is very short, the MG estimator does not have sufficient degrees of freedom. A Hausman test can be verify whether a significant difference exists between the PMG and MG.

\footnotetext{
${ }^{6}$ According to Acaravci and Ozturk (2012) and Pesaran and Shin (1995, 1998), the SBC is generally used in preference to other criteria because it tends to define more parsimonious specifications. In this research, the small data sample is another reason to prefer SBC. If the ARDL model is chosen by AIC instead, the estimates lack desirable properties. This is because SBC has consistent model selection criterion. For details, see Hasem and Shin (1999).
} 
The null hypothesis is that the difference between PMG and MG estimations is not significant. If the null hypothesis is not rejected, they are not significantly different; in this respect, we use the $\mathrm{PMG}$ estimator.

\section{Empirical Results}

\section{A. Manufacturing exports}

The definition of manufactured used here refers to manufactured goods by degree of manufacturing groupings (SITC Rev. 3). This definition is narrower than that used by production and employment statisticians. The SITC 3 classification, manufacturing exports are grouped into four categories based on extent of embodied skill and technology: (1) labor- and resource-intensive, (2) low-skill and technology-intensive, (3) medium-skill, and (4) high-skill and technology-intensive manufacturing exports. The composition of average manufacturing exports in East Africa for the years 1995 2013 is indicated in Table 1. The concentration of manufactures in resource-based products is particularly important given Eastern Africa's relative abundance of natural resources, thus highlighting a degree of specialization according to comparative advantage. Madagascar, Mauritius, and Ethiopia are leaders in generating a high proportion of laborand resource-intensive manufacturing exports. A fallacy for this region is that high-skill manufacturing exports are more prevalent than low- and medium-skill manufacturing exports. One possible explanation for this perception is the increasing of share of FDI manufacturing exports to total manufacturing exports. For example, in Rwanda (up to $80 \%$ ) and Ethiopia (75\%), followed by Kenya and Nigeria (approximately 25\%) of FDI export manufacturing may be linked to construction material production such as cement (Balchin et al. 2016). These FDI companies are very big and tend to focus on production and manufacturing of high-skilled and technology-intensive manufacturing exports rather than medium-skill manufacturing exports. This pattern is also present in Tunisia and Jordan, where high-skill and high-technology-intensive manufacturing exports are higher than medium-skill and technology-intensive manufacturing exports. In Tunisia, mean high-skill and technology-intensive manufacturing exports from 2003 2010 were $29.9 \%$ of total exports, whereas mean medium-skill and technology-intensive exports 
comprise only $11.2 \%$ of total manufacturing exports for the same year. Similarly, in Jordan, mean high-skill and technology-intensive manufacturing exports from 2003 2010 were $29.1 \%$ of total exports, whereas mean medium-skill and technologyintensive exports accounted for only $10.9 \%$ of total manufacturing exports for the same years (Diop and Ghali 2012)

Table 1. Composition of manufacturing exports for East African countries

(SITC 3 classifications, 1995 2013)

\begin{tabular}{|l|c|c|c|c|}
\hline Country & $\begin{array}{l}\text { Labor and } \\
\text { Resource- } \\
\text { Intensive }\end{array}$ & $\begin{array}{l}\text { Low skill and } \\
\text { Technology-Intensive }\end{array}$ & $\begin{array}{l}\text { Medium-Skill and } \\
\text { Technology-Incentive }\end{array}$ & $\begin{array}{l}\text { High-Skill and } \\
\text { Technology- } \\
\text { Intensive }\end{array}$ \\
\hline Burundi & 0.22 & 0.09 & 0.41 & 0.29 \\
\hline Ethiopia & 0.67 & 0.02 & 0.19 & 0.13 \\
\hline Kenya & 0.37 & 0.170 & 0.14 & 0.31 \\
\hline Madagascar & 0.83 & 0.03 & 0.04 & 0.10 \\
\hline Malawi & 0.58 & 0.03 & 0.15 & 0.24 \\
\hline Mauritius & 0.79 & 0.02 & 0.04 & 0.15 \\
\hline Rwanda & 0.23 & 0.16 & 0.34 & 0.27 \\
\hline Seychelles & 0.05 & 0.12 & 0.16 & 0.68 \\
\hline Tanzania & 0.46 & 0.09 & 0.22 & 0.23 \\
\hline Uganda & 0.23 & 0.19 & 0.22 & 0.37 \\
\hline Average & 0.44 & 0.09 & 0.19 & 0.28 \\
\hline
\end{tabular}

(Note) The figure is percentage of total merchandise exports.

(Source) Author's calculation based on United Nation Trade and Conference data 


\section{Figure 1. Trends in manufacturing exports and real effective exchange rates}

$(1995 \sim 2013)$

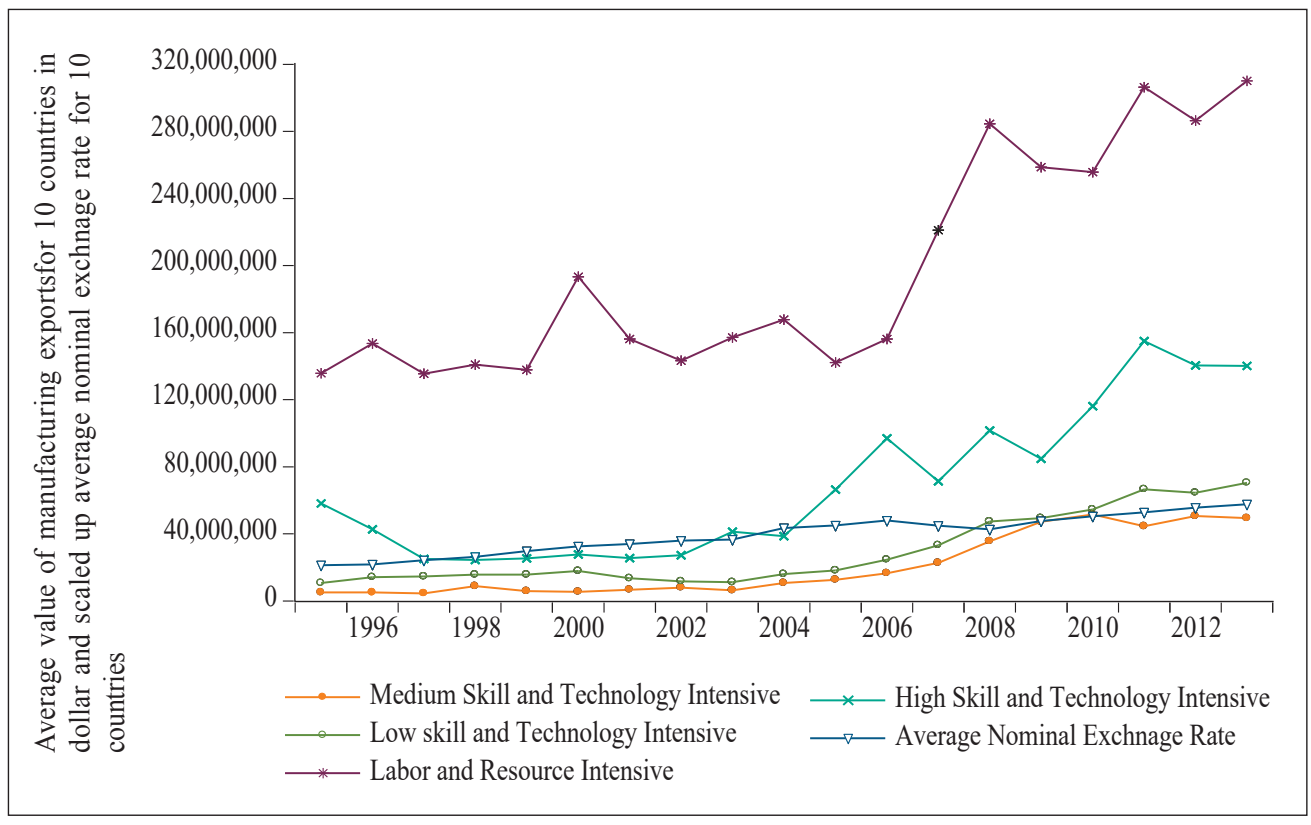

(Note) ( i ) Real Effective Exchange Rate is scaled by $10000 \%$.

(ii) The figure is constructed by using E-views 9.

(iii) Value of dollar in terms of domestic currency.

(Source) Author's calculation

Figure 1 shows the trend for average manufacturing exports in each classification along with the REER for 10 East African countries. The relationship trend between REER vis a vis the countries' top trade partners' currencies and average manufacturing exports is largely positive. As expected, eliminating currency overvaluation significantly increases the share of manufactured goods exports by making domestic sales less attractive. Although it cannot be determined whether depreciation of the REER promotes production of manufactured goods from the descriptive result, it does confirm that, although overvaluation of the REER is harmful to industrial exports, undervaluation increases manufactured exports. This descriptive result will be checked through an econometric investigation in section three. 


\section{B. Stationarity and cointegration tests}

This study uses LLC panel unit root tests to check variables' stationarity in each manufacturing export classification. The results suggest that most variables are $I(1)$; however, several variables may be regarded as $I(0)$. Detailed results are reported in Table 2. Before conducting stationarity tests, the lag length for the data is chosen based on SBC, and the optimum order of lag is one for all sectors. The long-term relationships among variables is checked using the Pedroni (1999, 2004) method for panel cointegration.

Table 2. Panel unit root test

\begin{tabular}{|c|c|c|c|c|}
\hline \multirow[b]{2}{*}{ Variables } & \multicolumn{2}{|c|}{ With intercept only } & \multicolumn{2}{|c|}{ With both intercept and trend } \\
\hline & $\mathrm{I}(\mathbf{0})$ & $\mathrm{I}(1)$ & $\mathrm{I}(\mathbf{0})$ & $\mathrm{I}(\mathbf{1})$ \\
\hline \multirow[t]{2}{*}{$\operatorname{Ln}(X l)$} & $-2.835 * * *$ & $-7.505 * * *$ & $-2.954 * * *$ & $-6.968 * * *$ \\
\hline & $(0.002)$ & $(0.000)$ & $(-0.002)$ & $(0.000)$ \\
\hline \multirow[t]{2}{*}{$\operatorname{Ln}(X l s)$} & $-1.610^{*}$ & $-4.682 * * *$ & $-2.117 * *$ & $-2.220 * *$ \\
\hline & $(0.054)$ & $(0.000)$ & $(0.017)$ & $(0.013)$ \\
\hline \multirow[t]{2}{*}{$\operatorname{Ln}(X m s)$} & 0.309 & $-1.619 * *$ & 0.484 & $-0.816^{*}$ \\
\hline & $(0.622)$ & $(0.053)$ & $(0.686)$ & $(0.07)$ \\
\hline \multirow[t]{2}{*}{$\operatorname{Ln}(X h t)$} & $-3.709 * * *$ & $-2.943 * * *$ & $-4.549 * * *$ & $-3.462 * *$ \\
\hline & $(0.000)$ & $(0.002)$ & $(0.000)$ & $(0.000)$ \\
\hline \multirow[t]{2}{*}{$\operatorname{Ln}(X m)$} & 0.395 & $-2.037 * *$ & $-3.586 * * *$ & $-1.331^{*}$ \\
\hline & 0.654 & $(0.021)$ & $(0.000)$ & $(0.092)$ \\
\hline \multirow[t]{2}{*}{$\operatorname{Ln}(R E E R)$} & -0.977 & $-1.025^{*}$ & $-6.363^{* * *}$ & $-6.194 * * *$ \\
\hline & $(0.164)$ & $(0.053)$ & $(0.000)$ & $(0.000)$ \\
\hline \multirow[t]{2}{*}{$\operatorname{Ln}(Y d)$} & -0.907 & -7.489 & $-4.709 * * *$ & $-4.218 * * *$ \\
\hline & $(0.182)$ & $(0.000)$ & $(0.000)$ & $(0.000)$ \\
\hline \multirow[t]{2}{*}{$\operatorname{Ln}(Y f)$} & $-2.712 * * *$ & $-2.973 * * *$ & $-7.533^{* * *}$ & $-6.969 * * *$ \\
\hline & $(0.233)$ & $(0.002)$ & $(0.000)$ & $(0.000)$ \\
\hline
\end{tabular}

(Note) "I(0)" and "I(1)" indicate that the series are evaluated at the level and at first difference, respectively. $L n$, REER, $Y d$, and $Y$ frepresent natural logarithm, REER, domestic real GDP, and foreign real GDP, respectively. $X l, X l s, X m s, X h t$, and $X m$ represent labor-intensive, low-skill, medium-skill, high-skill, and total manufacturing exports, respectively.

(Source) Author's calculation using E-views 9 
Table 3 shows the computed Pedroni's test results both with and without intercepts for all manufacturing export classifications. The empirical results allow rejection of the null hypothesis of no cointegration in all manufacturing classification exports for the majority of tests. Generally, although not with all tests, strong evidence of cointegration between these series was found. Pedroni $(1999,2004)$ showed that the panel ADF and group ADF tests have better small-sample properties than other tests; hence, their results are more reliable. In this empirical study, $\mathrm{ADF}$ and group $\mathrm{ADF}$ test results confirm the existence of a long-run relationship among exports, REER, a country's own real GDP, and tradeweighted foreign real GDP in all classifications of manufacturing exports.

Table 3. Panel cointegration test

\begin{tabular}{|l|c|c|}
\hline \multicolumn{1}{|c|}{ Test } & Statistics & P-Value \\
\hline Aggregate Manufacturing Exports & & \\
\hline Within Dimension & & \\
\hline Panel v-Statistic & 1.266 & 0.103 \\
\hline Panel rho-Statistic & -1.704 & 0.044 \\
\hline Panel PP-Statistic & -4.694 & 0.000 \\
\hline Panel ADF-Statistic & -5.040 & 0.000 \\
\hline Between Dimension & 0.213 & \\
\hline Group rho-Statistic & -3.784 & 0.584 \\
\hline Group PP-Statistic & -3.782 & 0.000 \\
\hline Group ADF-Statistic & & 0.000 \\
\hline Labor-Intensive & & \\
\hline Within Dimension & -2.772 & \\
\hline Panel v-Statistic & 0.583 & 0.997 \\
\hline Panel rho-Statistic & -1.159 & 0.720 \\
\hline Panel PP-Statistic & -0.983 & 0.123 \\
\hline Panel ADF-Statistic & -2.772 & 0.163 \\
\hline Between Dimension & 0.583 & 0.997 \\
\hline Group rho-Statistic & -1.159 & 0.720 \\
\hline Group PP-Statistic & -0.983 & 0.123 \\
\hline Group ADF-Statistic & & 0.163 \\
\hline
\end{tabular}


(continued)

\begin{tabular}{|c|c|c|}
\hline Test & Statistics & P-Value \\
\hline \multicolumn{3}{|l|}{ Low Skill } \\
\hline \multicolumn{3}{|l|}{ Within Dimension } \\
\hline Panel v-Statistic & 1.728 & 0.042 \\
\hline Panel rho-Statistic & -0.431 & 0.333 \\
\hline Panel PP-Statistic & -2.472 & 0.007 \\
\hline Panel ADF-Statistic & -2.699 & 0.004 \\
\hline \multicolumn{3}{|l|}{ Between Dimension } \\
\hline Group rho-Statistic & 0.802 & 0.789 \\
\hline Group PP-Statistic & -2.558 & 0.005 \\
\hline Group ADF-Statistic & -4.560 & 0.000 \\
\hline \multicolumn{3}{|l|}{ Medium Skill } \\
\hline \multicolumn{3}{|l|}{ Within Dimension } \\
\hline Panel v-Statistic & 1.146 & 0.126 \\
\hline Panel rho-Statistic & -0.932 & 0.176 \\
\hline Panel PP-Statistic & -3.432 & 0.000 \\
\hline Panel ADF-Statistic & -2.956 & 0.002 \\
\hline \multicolumn{3}{|l|}{ Between Dimension } \\
\hline Group rho-Statistic & 0.154 & 0.561 \\
\hline Group PP-Statistic & -4.107 & 0.000 \\
\hline \multicolumn{3}{|c|}{ High-Skill and Technology-Intensive } \\
\hline \multicolumn{3}{|l|}{ Within Dimension } \\
\hline Panel v-Statistic & 0.779 & 0.218 \\
\hline Panel rho-Statistic & -0.718 & 0.236 \\
\hline Panel PP-Statistic & -2.413 & 0.008 \\
\hline Panel ADF-Statistic & -2.425 & 0.008 \\
\hline \multicolumn{3}{|l|}{ Between Dimension } \\
\hline Group rho-Statistic & -0.001 & 0.500 \\
\hline Group PP-Statistic & -3.577 & 0.000 \\
\hline Group ADF-Statistic & -3.902 & 0.000 \\
\hline
\end{tabular}

(Note) Since ADF and group ADF tests have better small-sample properties than other tests and our study uses small observation, these two tests are used for cointegration tests. 


\section{Long- and short-run elasticities}

Table 4 shows the long-run, short-run, and error-correction coefficients for the four classifications of manufacturing exports and all explanatory variables. Given the existence of cointegration among variables, the long-run relationship is estimated using the PMG and MG estimators. The long-run coefficients estimated from the MG estimator are statistically insignificant for all classifications of manufacturing exports. A Hausman test confirmed that the null hypothesis of long-run homogeneity for each variable cannot be rejected at a 5\% significance level. Therefore, the PMG estimator is consistent and efficient under long-run homogeneity. The PMG estimation for elasticities of real exports with respect to REER is positive for labor-intensive, low-skill, mediumskill, high-skill, and technology-intensive manufacturing exports. A $1 \%$ devaluation of the REER improves exports by approximately $0.8 \%, 1.2 \%, 0.5 \%, 0.5 \%$, and $0.6 \%$ in labor-intensive, low-skill, medium-skill, high-skill, and aggregate manufacturing exports, respectively. This estimate is statistically significant at $1 \%$ for labor-intensive, low-skill, high-skill, and technology-intensive exports and significant at 5\% for medium-skill and total manufacturing exports. This positive effect is consistent with conventional theory. These findings indicate that devaluation of REER effects tend to be positive for all classifications of manufacturing exports in East African countries. The elasticities for all classifications of manufacturing exports are below one, except for that of lowskill manufacturing exports. The estimated exchange-rate elasticities range between 0.5 (medium skill) to $1.2 \%$ (low skill). A 1\% devaluation improves aggregate manufacturing exports by $0.6 \%$ in Eastern Africa. Therefore, East African-manufactured exports seem to be responsive to incentives: depreciation clearly fosters export performance. Nevertheless, the magnitude of these elasticities remains below the findings for SubSaharan African countries (1.2\%) and other developing countries (Khalid and Aristomene 2000) reported in comparable studies. For instance, the elasticities reported by Grobar (1993) are, in general, three times -between 1 and 3.26-as the ones found in this study. Although East African exporters are responsive to incentive mechanisms, they appear less responsive than other developing-country exporters. The predominance of inferior manufacturing exports in the global market, high inflation, high dependency on imported inputs for manufacturing processing, among others, are possible reasons for the low manufacturing export elasticity with respect to exchange rates in East African countries. 


\begin{tabular}{|c|c|c|c|c|c|c|c|c|c|c|c|c|c|c|c|c|c|c|c|}
\hline$\stackrel{U}{\Sigma}$ & $\stackrel{\grave{\Xi}}{\vec{\nabla}}$ & & f & $\begin{array}{c}\infty \\
\tilde{e} \\
\stackrel{?}{e}\end{array}$ & శ్ & $\begin{array}{l}\tilde{0} \\
\stackrel{\infty}{\infty}\end{array}$ & $\stackrel{\infty}{\infty}$ & $\underset{f}{\stackrel{f}{f}}$ & & \begin{tabular}{l}
$*$ \\
$*$ \\
$*$ \\
\multirow{*}{*}{} \\
$\stackrel{1}{0}$
\end{tabular} & 8 & $\stackrel{0}{\circ}$ & $\begin{array}{l}\overparen{J} \\
\stackrel{\infty}{e}\end{array}$ & $\stackrel{\sim}{n}$ & $\stackrel{\text { t. }}{e}$ & $\stackrel{\text { 草 }}{\pi}$ & $\widehat{\vec{\sigma}}$ & & \\
\hline$\sum_{i}^{U}$ & 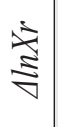 & & 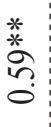 & $\overparen{\Xi}$ & $\begin{array}{l}* \\
* \\
* \\
*\end{array}$ & $\stackrel{\overparen{8}}{\stackrel{8}{e}}$ & $\stackrel{*}{*}$ & $\overparen{\hat{\theta}}$ & & $\begin{array}{l}* \\
* \\
* \\
* \\
+ \\
+\end{array}$ & $\begin{array}{l}8 \\
8\end{array}$ & \begin{tabular}{l}
\multirow{8}{0}{} \\
$\stackrel{0}{0}$ \\
\end{tabular} & $\widehat{\varrho}$ & $\tilde{n}$ & $\begin{array}{l}\overparen{\hat{\sigma}} \\
\dot{\theta}\end{array}$ & $\begin{array}{l}\stackrel{*}{*} \\
\stackrel{*}{*} \\
\sigma\end{array}$ & $\begin{array}{l}8 \\
0\end{array}$ & & \\
\hline$\stackrel{U}{\Sigma}$ & 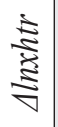 & & $\underset{T}{\overbrace{}}$ & $\frac{\widehat{\curvearrowright}}{\stackrel{e}{e}}$ & $\underset{\sim}{J}$ & $\underset{\widetilde{త}}{\stackrel{\overbrace{}}{e}}$ & $\stackrel{+}{\stackrel{2}{0}}$ & $\begin{array}{l}\hat{\theta} \\
\infty \\
\stackrel{e}{e}\end{array}$ & & $\stackrel{\stackrel{*}{*}}{\stackrel{*}{\Im}}$ & $\begin{array}{l}\sigma \\
\theta\end{array}$ & $\left\{\begin{array}{l}* \\
\stackrel{*}{*} \\
\stackrel{*}{\top}\end{array}\right.$ & $\stackrel{\overparen{8}}{\stackrel{8}{0}}$ & $\stackrel{ }{\Im}$ & $\begin{array}{l}\overparen{\sigma} \\
\stackrel{e}{e}\end{array}$ & $\begin{array}{l}\begin{array}{l}* \\
0 \\
0 \\
i\end{array} \\
\dot{n}\end{array}$ & $\begin{array}{l}8 \\
\stackrel{8}{e}\end{array}$ & & \\
\hline$\sum_{i}^{U}$ & 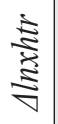 & & \begin{tabular}{l}
$*$ \\
$*$ \\
$*$ \\
\multirow{*}{*}{} \\
\multirow{2}{*}{}
\end{tabular} & $\stackrel{8}{8}$ & 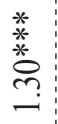 & $\begin{array}{l}\overparen{8} \\
\stackrel{0}{9}\end{array}$ & $\frac{*}{*}$ & $\begin{array}{l}\widehat{8} \\
\stackrel{e}{e}\end{array}$ & & 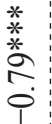 & $\begin{array}{l}\widehat{\theta} \\
0\end{array}$ & $\frac{*}{\sigma}$ & $\stackrel{6}{8}$ & $\begin{array}{l}\overrightarrow{+} \\
\stackrel{\varphi}{0}\end{array}$ & $\begin{array}{l}\hat{8} \\
\stackrel{9}{9}\end{array}$ & 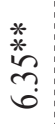 & $\begin{array}{l}\overparen{\delta} \\
\stackrel{0}{\varrho}\end{array}$ & & \\
\hline$\stackrel{U}{\Sigma}$ & 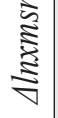 & & 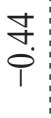 & $\begin{array}{l}6 \\
\stackrel{8}{0} \\
0\end{array}$ & $\vec{\infty}$ & $\underset{\widetilde{త}}{\widehat{\Theta}}$ & $\frac{7}{r}$ & $\stackrel{\tilde{n}}{e}$ & & \begin{tabular}{l}
$*$ \\
$*$ \\
\multirow{*}{*}{} \\
$\stackrel{\varphi}{\alpha}$
\end{tabular} & $\begin{array}{l}8 \\
0\end{array}$ & $\vec{\sigma}$ & $\stackrel{\tilde{n}}{e}$ & ñ & $\widehat{\widehat{\sigma}}$ & $\stackrel{尺}{\forall}$ & $\frac{\tilde{n}}{e}$ & & \\
\hline$\sum_{i}^{U}$ & 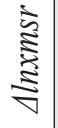 & & 苂 & $\begin{array}{l}\overparen{\delta} \\
\stackrel{\Xi}{\ominus}\end{array}$ & $\begin{array}{l}\text { ** } \\
\stackrel{*}{*} \\
\stackrel{\text { c }}{*}\end{array}$ & $\stackrel{\overparen{8}}{\stackrel{8}{e}}$ & $\stackrel{+}{\stackrel{2}{0}}$ & $\stackrel{\overparen{\sigma}}{\stackrel{\mathfrak{c}}{e}}$ & & $\begin{array}{l}\stackrel{*}{*} \\
\stackrel{*}{*} \\
\stackrel{0}{0}\end{array}$ & $\begin{array}{l}8 \\
8\end{array}$ & $\stackrel{\circ}{\circ}$ & $\begin{array}{l}\overparen{d} \\
\stackrel{\infty}{\ominus}\end{array}$ & 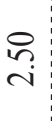 & $\stackrel{\overbrace{}}{\stackrel{p}{\ominus}}$ & $\begin{array}{l}\frac{*}{*} \\
\stackrel{*}{6} \\
\stackrel{*}{6}\end{array}$ & $\begin{array}{l}\vec{\sigma} \\
\stackrel{e}{e}\end{array}$ & & \\
\hline$\stackrel{U}{\Sigma}$ & $\begin{array}{l}\frac{3}{3} \\
\stackrel{3}{\Xi}\end{array}$ & & $\bar{n}$ & 胥 & $\underset{+}{\stackrel{P}{+}}$ & $\frac{\infty}{\stackrel{\infty}{e}}$ & 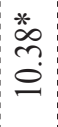 & $\stackrel{\widehat{\hat{\theta}}}{\stackrel{e}{e}}$ & & \begin{tabular}{l}
$*$ \\
$\stackrel{*}{*}$ \\
\multirow{*}{*}{}
\end{tabular} & $\begin{array}{l}8 \\
8\end{array}$ & $\stackrel{n}{\circ}$ & 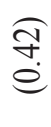 & $\begin{array}{l}0 \\
\text { ?n? } \\
\text { ? }\end{array}$ & $\begin{array}{l}\widehat{\sigma} \\
\stackrel{e}{e}\end{array}$ & $\underset{+}{F}$ & 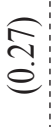 & & \\
\hline$\sum_{\Omega}^{U}$ & $\frac{\substack{\overrightarrow{3} \\
\vdots}}{\nabla}$ & & $\begin{array}{l}* \\
* \\
* \\
\text { * } \\
\end{array}$ & $\stackrel{8}{8}$ & 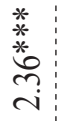 & $\stackrel{\overparen{8}}{\stackrel{8}{e}}$ & ळ & $\frac{\widehat{\Im}}{\vec{e}}$ & & \begin{tabular}{l} 
* \\
* \\
\multirow{+}{*}{} \\
$\stackrel{9}{+}$
\end{tabular} & $\begin{array}{l}8 \\
0\end{array}$ & $\stackrel{+}{\stackrel{0}{0}}$ & $\stackrel{\overparen{\nexists}}{\stackrel{f}{e}}$ & $\stackrel{\text { I }}{0}$ & $\begin{array}{l}\hat{2} \\
\infty \\
e\end{array}$ & \begin{tabular}{l}
$\stackrel{*}{*}$ \\
\multirow{*}{*}{} \\
$\stackrel{\infty}{r}$ \\
-
\end{tabular} & $\begin{array}{l}\tilde{8} \\
8 \\
\varrho\end{array}$ & & \\
\hline$\stackrel{U}{\Sigma}$ & 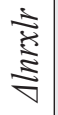 & & 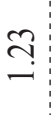 & 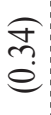 & $\stackrel{\mathcal{F}}{T}$ & $\begin{array}{l}\hat{\sigma} \\
\stackrel{?}{e}\end{array}$ & $\begin{array}{l}\infty \\
\infty \\
n\end{array}$ & $\underset{\overbrace{}}{\tilde{e}}$ & & \begin{tabular}{l}
$*$ \\
$*$ \\
\multirow{2}{*}{} \\
$\infty$ \\
$\infty$ \\
0
\end{tabular} & $\begin{array}{l}\widehat{\theta} \\
\dot{\theta}\end{array}$ & $\stackrel{2}{9}$ & $\stackrel{\overbrace{}}{\stackrel{f}{e}}$ & $\underset{\dot{\nabla}}{\vec{\nabla}}$ & $\stackrel{\tilde{m}}{\tilde{e}}$ & $\begin{array}{l}* \\
* \\
\infty \\
\stackrel{*}{*}\end{array}$ & $\begin{array}{l}\overparen{\Xi} \\
\stackrel{\Xi}{\varrho}\end{array}$ & $\stackrel{8}{\circ}$ & 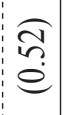 \\
\hline 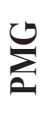 & 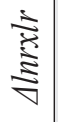 & & $\begin{array}{l}* * \\
* \\
* \\
0 \\
0\end{array}$ & $\begin{array}{l}8 \\
\stackrel{8}{0}\end{array}$ & 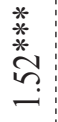 & $\stackrel{\overparen{8}}{\stackrel{8}{e}}$ & ๙ૂ & $\frac{\overparen{\Xi}}{\mathfrak{e}}$ & & $\begin{array}{l}* \\
* \\
* \\
\infty \\
n \\
\vdots\end{array}$ & $\begin{array}{l}8 \\
8\end{array}$ & ๙ึ? & $\begin{array}{l}\text { है } \\
\stackrel{n}{e}\end{array}$ & $\begin{array}{l}\infty \\
m \\
0\end{array}$ & 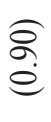 & \begin{tabular}{l}
$\stackrel{*}{*}$ \\
\multirow{\delta}{*}{} \\
+
\end{tabular} & శ్ & ஓे. & $\begin{array}{l}\tilde{\tilde{e}} \\
\stackrel{e}{0}\end{array}$ \\
\hline & & 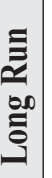 & 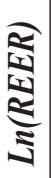 & & $\underset{\Xi}{\Xi}$ & & $\underset{\mathrm{J}}{\mathrm{S}}$ & & 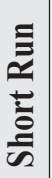 & $\underset{+1}{0}$ & & 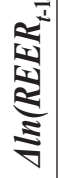 & & 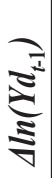 & & $\underset{\Xi}{\frac{1}{\nabla}}$ & & $\frac{27}{\nabla}$ & \\
\hline
\end{tabular}




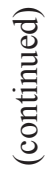

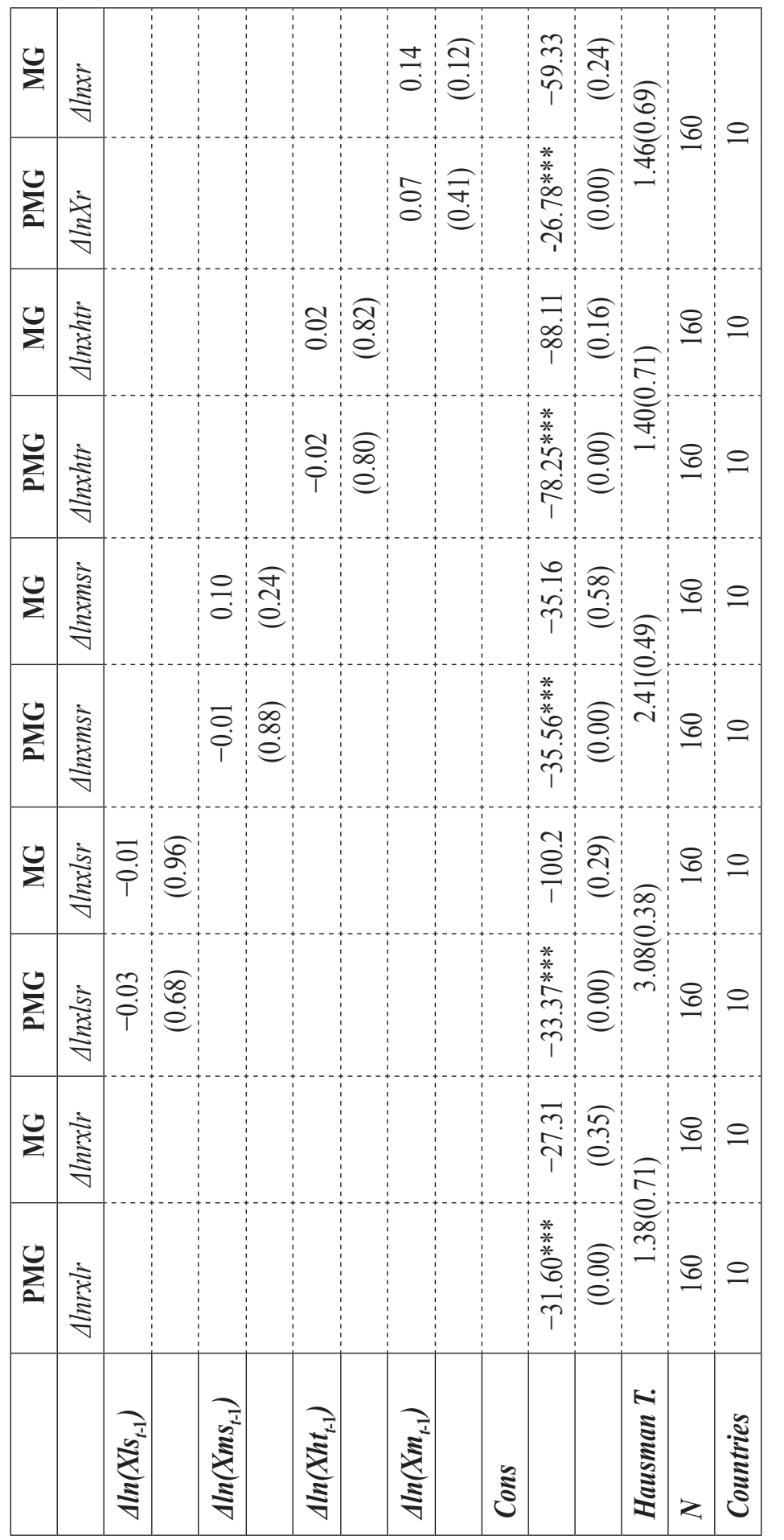

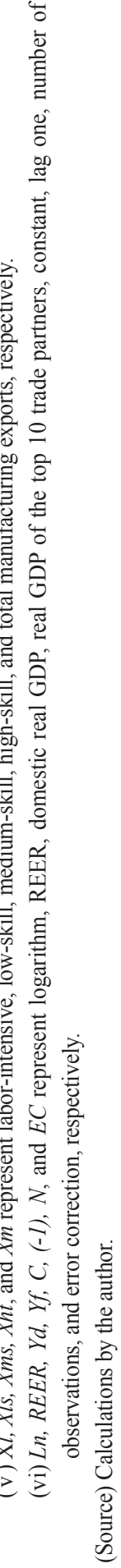


The theory on the relationship between exports and real income is ambiguous. Higher real GDP level stimulates demand for imports and increases the supply of domestic production of tradable goods, leaving the ultimate impact on the ratio of exports to imports somewhat indeterminate and essentially an empirical issue. However, our empirical results show that as a country's own real GDP increases, manufacturing exports increase in all classifications. Table 4 demonstrates that the elasticity of manufacturing exports with respect to domestic real GDP is positive and statistically significant at $1 \%$ for all classifications. A $1 \%$ increase in domestic real GDP increases real exports by approximately $1.5 \%, 2.4 \%, 2.1 \%, 1.3 \%$, and $1.3 \%$ for labor-intensive, lowskill, medium-skill, high-skill, and total manufacturing exports, respectively. The positive sign here points toward the important role played by supply-side factors in driving the output growth of these countries. The elasticities in all classifications of manufacturing exports are higher than one. This shows that all classifications of manufacturing exports have more response to domestic real economic growth than a devaluation of the REER.

According to the traditional theory, an increase foreign real GDP has a positive effect on exports. This positive effect holds for all classifications of manufacturing exports, but is significant only for high-skill and technology-intensive manufacturing exports at $1 \%$ and $5 \%$, respectively.

Table 4 also lists the short-run and error-correction term coefficients. Apart from a robust a long-run relationship, our short-run error correction estimation is statistically well-behaved. The Error-Correction Term (ECT) coefficient has a negative sign and is statistically significant at 5\% for all classifications of manufacturing exports. A negative coefficient ensures that the series is non-explosive so that long-run equilibrium can be attained. The magnitude of ECT estimates measures the single-period response of the dependent variable to its deviation from the equilibrium. For example, in the case of the high-skill, technology-intensive manufacturing export classification, the ECT value is -0.79 . This value indicates that a deviation of exports from the long-run equilibrium due to shock in the previous year is corrected by about $79 \%$ in the current year. The result indicates that convergence to the equilibrium is swift following a shock. In comparison, in the low-skill classification of manufacturing exports, the ECT is -0.43 ; this shows that the speed of adjustment is relatively slow in this sector. Thus, the speed of adjustment varies from -0.43 to -0.79 , which may be attributed to the difference in competitiveness among different manufacturing export classifications (Kyophilavong et al. 2013).

In labor-intensive, low-skill, and medium-skill manufacturing exports, short-run real effective foreign exchange rate elasticity is positive but not statistically significant. The 
sign is negative for high-skill, technology-intensive, and total manufacturing exports, but is statistically significant only for high-skill, technology-intensive manufacturing exports. The intuition here is that insignificance of labor-intensive, low-skill, and mediumskill manufacturing exports in East Africa are due to the predominance of inferior manufacturing exports in the global market, high inflation, high dependency on imported inputs for manufacturing processing, low infrastructure (Arora, Bahmani-Oskooee and Goswami 2003); (Rakotoarisoa, Iafrate and Paschali 2011), and low fiscal and monetary discipline (Mahle et al. 2013). For example, according to Mahle et al. (2013), larger real exchange volatility, overdependence on tobacco exports, low policy credibility, and higher inflation make devaluation ineffective in Malawi. As result, in the short run, the volume effect of exports is less than the price effect.

\section{Conclusion}

This study investigated short-and long-run effects of exchange rates on manufacturing exports classified by material in 10 East African countries using PMG and MG estimators of the ARDL model. The existence of a long-run relationship among variables was confirmed for all manufacturing exports.

The empirical estimations results suggested that depreciation of the REER improves all types of manufacturing exports in long-run, a result that is statistically significant and consistent with the standard theory. However, the long-run elasticity of manufacturing exports with respect to REER is relatively small, except for low-skill manufacturing exports. The magnitude of the elasticities remains below the findings for Sub-Saharan African countries (1.2\%) and other developing countries (1 and 3.26).

In the short run, depreciation of the RER improves labor-intensive, low-skill, and medium-skill manufacturing exports. In contrast, depreciation of the REER worsens high-skill and technology-intensive exports. The empirical estimate showed that RER depreciation improves aggregate manufacturing exports, but this finding was not insignificant. An increase in real GDP bosts manufacturing exports, and the coffieicent was statistically significant. Similarly, increases in foreign real GDP improve all manufacturing exports classified by material, but this effect is statstically signficant only for high-skill manufacturing and aggregate manufacturing exports. This is possibly 
because the response of high-skill exports with respect to exchange rates is higher than the response of labor-intensive, low-skill, and medium-skill exports with respect to the REER. In addition, aggregate manufacturing exports' response with respect to the REER is statistically significant in reflection of high-skill intensive manufacturing exports.

Our findings suggest that exchange rate devaluations matter for export performance in Eastern Africa. Nevertheless, the magnitude of such elasticity is low and remains below level found for Sub-Saharan African and other developing countries. A positive and elastic relationship between manufacturing exports and domestic real GDP shows the importance of economic growth to the performance of manufacturing exports. Therefore, policies aimed at boosting manufacturing exports in the long term are suggested as a way to provide a conducive environment for manufacturing exports prior to continuous devaluation of the domestic currency.

Received 10 August 2017, Revised 11 October 2017, Accepted 6 November 2017

\section{References}

Acaravci, Ali, and Ilhan Ozturk. "Foreign direct investment, export and economic growth: empirical evidence from new EU countries." Romanian Journal of Economic Forecasting 2 (2012): 52-67.

Asteriou, D., and S. G. Hall. "Applied econometrics: A modern approach using eviews and microfit revised edition: Palgrave Macmillan." (2007).

Asian Development Bank. Asian Development Outlook 2007. Manila

Amakom, Uzochukwu. "Manufactured exports in sub-saharan African economies: Econometric tests for the learning by exporting hypothesis." American International Journal of Contemporary Research 2, no. 4 (2012): 195-206.

Arora, Swarnjit, Mohsen Bahmani-Oskooee, and Gour Goswami. "Bilateral J-curve 
between India and her trading partners." Applied Economics 35, no. 9 (2003): 10371041

Bahmani-Oskooee, Mohsen, and Yongqing Wang. "The J-curve: evidence from commodity trade between US and China." Applied Economics 40, no. 21 (2008): 2735-2747.

Bigsten, Arne, Paul Collier, Stefan Dercon, Marcel Fafchamps, Bernard Gauthier, Jan Willem Gunning, A. Oduro et al. Exporting and Efficiency in African Manufacturing. Paris: OECD Development Centre. 2001.

Boumbouya, Raymond K. Exchange rate change, the trade balance and output growth in developing countries: Evidence from the CFA Franc Zone. American University, 2009.

Balchin, Neil, Stephen Gelb, Jane Kennan, Hope Martin, Dirk Willem te Velde, and Carolin Williams. "Developing export-based manufacturing in sub-Saharan Africa." London: Overseas Development Institute (2016).

Chenery, Hollis B., Sherman Robinson, and Moshe Syrquin. Industrialization and growth. Washington: World Bank, 1986.

Chinn, Menzie D. "A primer on real effective exchange rates: Determinants, overvaluation, trade flows and competitive devaluation." Open economies review 17 , no. 1 (2006): 115-143.

Collier, Paul, and Jan Willem Gunning. "Explaining African economic performance." Journal of economic literature 37, no. 1 (1999): 64-111.

Diop, Ndiame, and Sofiane Ghali. "Are Jordan and Tunisia's Exports Becoming More Technologically Sophisticated? Analysis Using Highly Disaggregated Export Databases." (2012).

Dornbusch, Rudiger. Open economy macroeconomics. No. 1980. New York: Basic Books, 1980.

Elbadawi, Ibrahim. Can Africa Export Manufactures?: The Role of Endowment, 
Exchange Rates and Transaction Costs. vol. 2120. World Bank Publications, 1999.

Engle, Robert F., and Clive WJ Granger. "Co-integration and error correction: representation, estimation, and testing." Econometrica: journal of the Econometric Society (1987): 251-276.

Frankel, Jeffrey A., and David Romer. "Does trade cause growth?" American economic review (1999): 379-399.

Grobar, Lisa Morris. "The effect of real exchange rate uncertainty on LDC manufactured exports." Journal of Development Economics 41, no. 2 (1993): 367-376.

Gujarati, Damodar N. Basic econometrics. Tata McGraw-Hill Education, 2009.

Harris, Richard, and Robert Sollis. Applied time series modelling and forecasting. Wiley, 2003.

Hausmann, Ricardo, Lant Pritchett, and Dani Rodrik. "Growth accelerations." Journal of Economic Growth 10, no. 4 (2005): 303-329.

Kyophilavong, Phouphet, Muhammad Shahbaz, and Gazi Salah Uddin. "Does J-curve phenomenon exist in case of Laos? An ARDL approach." Economic Modelling 35 (2013): 833-839.

Lewis, W. Arthur. "Economic development with unlimited supplies of labour." The manchester school 22, no. 2 (1954): 139-191.

Nouira, Ridha, Patrick Plane, and Khalid Sekkat. "Exchange rate undervaluation and manufactured exports: A deliberate strategy?" Journal of comparative economics 39, no. 4 (2011): 584-601.

Mahle, Nils, Haimanot Teferra, and Armine Khachatryan. "Exchange Rate Liberalization in Selected Sub-Saharan African Countries Successes, Failures, and Lessons." (2013).

Pedroni, Peter. "Critical values for cointegration tests in heterogeneous panels with multiple regressors." Oxford Bulletin of Economics and statistics 61, no. S1 (1999): 
653-670.

Pedroni, Peter. "Panel cointegration: asymptotic and finite sample properties of pooled time series tests with an application to the PPP hypothesis." Econometric theory 20, no. 3 (2004): 597-625.

Pesaran, M. Hashem, and Ron Smith. "Estimating long-run relationships from dynamic heterogeneous panels." Journal of econometrics 68, no. 1 (1995): 79-113.

Pesaran, M. Hashem. "The role of economic theory in modelling the long run." The Economic Journal 107, no. 440 (1997): 178-191.

Pesaran, M. Hashem, and Yongcheol Shin. "An autoregressive distributed-lag modelling approach to cointegration analysis." Econometric Society Monographs 31 (1998): 371-413.

Pesaran, M. Hashem, Yongcheol Shin, and Ron P. Smith. "Pooled mean group estimation of dynamic heterogeneous panels." Journal of the American Statistical Association 94, no. 446 (1999): 621-634.

Sekkat, Khalid, and Aristomene Varoudakis. "Exchange rate management and manufactured exports in Sub-Saharan Africa." Journal of Development Economics 61, no. 1 (2000): 237-253.

Toda, Hiro Y. "Finite sample performance of likelihood ratio tests for cointegrating ranks in vector autoregressions." Econometric theory 11, no. 5 (1995): 1015-1032.

Thapa, Nara Bahadur. "An econometric analysis of the impact of real effective exchange rate on economic activities in Nepal." Economic Review: Occasional Paper 14 (2002): 17-36.

Thorbecke, Willem, and Hanjiang Zhang. "The effect of exchange rate changes on china's labour-intensive manufacturing exports." Pacific Economic Review 14, no. 3 (2009): 398-409.

Zia, Uzma, and Zafar Mahmood. "Exchange rate depreciation and export price competitiveness: The case of Pakistani manufacturing industries." Journal of the Asia Pacific Economy18, no. 4 (2013): 529-542. 